\title{
MODAL SOSIAL DALAM USAHA CAPTIKUS DI DESA RANOLAMBOT KECAMATAN KAWANGKOAN BARAT
}

\author{
Martini Frinli Lomboan \\ Melsje Yellie Memah \\ Charles Reijaaldo Ngangi
}

\begin{tabular}{ll}
\hline Naskah diterima melalui Website Jurnal Ilmiah agrisosioekonomi@unsrat.ac.id & : Kamis, 24 Oktober 2019 \\
Disetujui diterbitkan & : Jumat, 25 Oktober 2019 \\
\hline
\end{tabular}

\begin{abstract}
This study aims to examine the social capital of the network, beliefs and social norms in captikus industries in Ranolambot Village, Kawangkoan Barat District, Minahasa Regency. This study uses primary data obtained through interviews using a questionnaire to 30 farmers who were chosen purposively. Secondary data was taken from the Village Office and other sources from the internet through Google searching to obtain books, articles and theses that discuss social capital in the agricultural processing industry. Data analysis using Likert scale and analyzed descriptively. The results of the study show that: (1) Social networks are in the Fairly Good category because networks with people outside the village are still lacking because when capturers and farmers in Ranolambot Village sell captics outside the village as well as outside companies, they must use intermediaries so that captikus will be sold. (2) Trust is in the Fairly Good category because Trust between the host and the captikus farmer must be further enhanced by mutual trust because when there are farmers who first take the money to the captikus the money should be replaced with the captikus but there are other farmers who do not return that money because it has moved to another colector trader. (3) Social norms are in the category of Good because the colector and the capticus farmer abide by all the rules that apply both fellow farmers and the colector with the government in the village, for example in the case of a captikus permits, before the capticus colector makes an effort to become their host used to make a license to collect capticus.
\end{abstract}

Keywords: trust, networks, social norms, traditional beverage-making farmers, captikus

\section{ABSTRAK}

Penelitian ini bertujuan untuk mengkaji modal sosial jaringan, kepercayaan dan norma sosial dalam usaha captikus di Desa Ranolambot Kecamatan Kawangkoan Barat Kabupaten Minahasa. Penelitian ini menggunakan data primer yang diperoleh melalui wawancara dengan menggunakan kuesioner kepada 30 petani captikus secara yang dipilih secara sengaja (purposive sampling). Data sekunder diambil dari Kantor Desa dan sumber lain dari internet melalui google searching untuk mendapatkan buku, artikel dan skripsi yang membahas tentang modal sosial dalam usaha industri pengolahan hasil pertanian. Analisis data menggunakan Skala likert dan dianalisis secara deskriptif. Hasil penelitian menunjukkan bahwa: (1) Jaringan sosial berada pada kategori Cukup Baik karena jaringan dengan orang di luar desa masih kurang karena ketika penampung dan petani captikus di Desa Ranolambot melakukan penjualan captikus di luar desa maupun di perusahanperusahan luar harus memakai perantara agar supaya captikus akan terjual. (2) Kepercayaan berada pada kategori Cukup Baik karena Kepercayaan antara penampung dan petani captikus harus lebih ditingkatkan lagi oleh rasa saling percaya karena ketika ada petani yang terlebih dahulu mengambil uang kepada penampung captikus seharusnya uang itu akan diganti dengan captikus tetapi ada petani lain yang tidak mengembalikan uang itu karena sudah berpindah ke penampung captikus yang lain. (3) Norma sosial berada pada kategori Baik dikarena penampung dan petani captikus mematuhi segala aturan-aturan yang berlaku baik sesama petani maupun penampung dengan pemerintah di Desa tersebut contohnya dalam hal surat ijin penampung captikus, sebelum penampung captikus melakukan usaha untuk menjadi penampung mereka sudah terlebih dahulu membuat surat ijin penampung captikus.

Kata kunci: kepercayaan, jaringan sosial, norma sosial, petani pengolah cap tikus 


\section{PENDAHULUAN}

\section{Latar Belakang}

Terdapat beberapa pilihan dalam upaya untuk memanfaatkan berbagai jenis tanaman potensial sebagai sumber bahan bakar nabati di Indonesia. Jenis tanaman potensial tersebut adalah pohon jarak, pohon aren, dan sebagainya. Salah satu peluang usaha tanaman potensial yang dimanfaatkan oleh masyarakat khususnya di Provinsi Sulawesi Utara adalah tanaman aren, enau, atau dikenal oleh masyakarat Minahasa adalah Pohon Seho. Pohon seho atau aren adalah palma yang terpenting setelah kelapa karena merupakan tanaman serba guna. Tumbuhan ini dikenal dengan berbagai nama di Indonesia seperti enau, hanau, peluluk, biluluk, kabung, taren, akol, akel, akere, inru, indu (bahasabahasa di Sulawesi); moka, moke, tuwa, tuak (di Nusa Tenggara), dan lain-lain.

Nira dapat diolah menjadi cairan beralkohol dalam bahasa Minahasa dikenal dengan nama "captikus". Captikus adalah salah satu kekayaan alam yang ada di daerah Minahasa, sadapan air nira dari mayang pohon aren diolah dengan proses penyulingan sehingga nira berubah menjadi sopi atau biasa disebut Captikus, yang digunakan oleh masyarakat untuk tradisi, adat, upacara, memanaskan tubuh, perayaan hari syukuran, penghiburan duka, pelengkap acara pertemuan sanak saudara, teman, dll.

Penggunaan captikus dalam adat Minahasa merupakan salah satu modal sosial yang harus dijaga dalam tradisi Minahasa. Khususnya tradisi yang ada di Desa Ranolambot diadakan tradisi ketika yang menggelar acara seperti acara ulang tahun dan pesta pernikahan maupun acara duka jadi captikus adalah minuman wajib yang disajikan oleh tuan rumah acara tersebut.

Modal sosial merupakan hal penting dalam pembangunan ekonomi. Modal sosial yang dibentuk berdasarkan kegiatan ekonomi dan sosial pandang sebagai faktor yang dapat meningkatkan kehidupan ekonomi secara luas. Jika digunakan secara tepat, modal sosial akan melahirkan serangkaian nilai-nilai atau norma-norma informal yang dimiliki bersama diantara para anggota suatu kelompok masyarakat yang memungkinkan terjalinnya kerjasama diantara mereka (Erani,2006).

Secara konsep, modal sosial memiliki dua aspek yaitu tingkat individu dan tingkat sosial dan pengukurannya harus menyinggung kedua tingkatan tersebut. Pengukuran modal sosial pada tingkat individu khususnya pada dimensi kognitif memunculkan ciri-ciri kolektif, yaitu seberapa besar rasa percaya individu terhadap orang lain atau seberapa besar individu menemukan norma yang dapat membangun kelompok, komunitas atau masyarakat.

Putnam dalam Anam (2013) mendefinisikan modal sosial sebagai penampilan organisisasi sosial seperti jaringan dan kepercayaan yang memfasilitas adanya koordinasi dan kerjasama bagi keuntungan bersama. Coleman dalam Mariani (2014), mendefinisikan modal sosial sebagai seperangkat sumber daya yang melekat pada hubungan keluarga dan dalam organisasi sosial komunitas dan yang berguna bagi perkembangan kognitif atau sosial anak atau orang yang masih mudah. Sumber-sumber daya tersebut berbeda bagi orang-orang yang berlainan dan dapat memberikan manfaat penting bagi anak-anak dan remaja bagi pengembangan modal sosial mereka.

Di Desa Ranolambot, modal sosial terjadi melalui hubungan antara penampung dan petani captikus. Hubungan tersebut dapat dilihat oleh adanya jaringan sosial, kepercayaan dan norma sosial yang terbentuk. Jaringan sosial penampung dan petani captikus terbentuk diantara sesama petani dalam meminjamkan pohon seho kepada petani yang lain yang membutuhkan. Pada umumnya penampung dan petani captikus saling percaya satu sama lain. Antara penampung dan petani captikus terdapat norma yang berupa aturan sistem kerja dan sistem bayar kinerja yang merupakan norma sosial yang berlaku di Desa.

\section{Rumusan Masalah}

Berdasarkan latar belakang yang dikemukakan maka permasalahannya adalah bagaimana modal sosial dalam jaringan, kepercayaan dan norma sosial dalam usaha captikus di Desa Ranolambot Kecamatan Kawangkoan Barat Kabupaten Minahasa?

\section{Tujuan Penelitian}

Penelitian ini bertujuan untuk mengkaji modal sosial jaringan, kepercayaan dan norma sosial dalam usaha captikus di Desa Ranolambot Kecamatan Kawangkoan Barat Kabupaten Minahasa. 


\section{Manfaat Penelitian}

1. Manfaat bagi penulis, yaituera untuk mengimplementasikan teori-teori yang diperoleh selama kuliah.

2. Memberikan sumbangan pemikiran kepada lembaga dalam rangka Studi Agribisnis.

3. Menghasilkan sebuah referensi ilmiah yang dapat membantu masyarakat khususnya pada usaha captikus yang ada di pedesaan.

\section{METODE PENELITIAN}

\section{Waktu dan Tempat Penelitian}

Penelitian ini dilakukan di Desa Ranolambot Kecamatan Kawangkoan Barat Kabupaten Minahasa. Penelitian ini berlangsung selama 4 bulan dari proses pengumpulan data sampai pengolahan data yaitu dari bulan Juni sampai September 2019.

\section{Metode Pengambilan Sampel}

Metode Pengambilan sampel yang digunakan adalah "purposive sampling". dimana teknik pengambilan sampel ini dengan cara sengaja mengambil kepada petani dan penampung captikus. Objek dalam penelitian ini adalah para petani Captikus dan penampung Captikus yang ada di Desa Ranolambot, dan jumlah responden yang digunakan dalam penelitian ini adalah 30 responden yang tersebar pada 5 jaga/dusun.

\section{Data yang digunakan}

Data diperoleh melalui data primer atau wawancara langsung kepada responden yang terdiri dari 5 responden petani captikus dan 1 responden penampung captikus di setiap lingkungan yang ada di Desa Ranolambot dengan menggunakan kuesioner yang disiapkan.

Data sekunder diperoleh melalui datadata tertulis yang ada di Kantor Desa serta literatur yang berasal dari perpustakaan dan internet.

\section{Metode Pengumpulan Data}

Pengambilan Data dengan menggunakan metode kualitatif melalui wawancara kepada petani dan penampung captikus yang dilakukan secara langsung dengan menggunakan kuesioner. Pada setiap lingkungan dalam 1 Desa tersebut terdapat sebanyak 5 Lingkungan yang ada di Desa Ranolambot dan terdiri dari 5 Petani Captikus dan 1 Penampung captikus disetiap Lingkungan.

\section{Konsep Pengukuran Variabel}

1. Karakteristik Responden, mencakup

a) Umur, yaitu umur Petani dan Pengepul Captikus

b) Tingkat Pendidikan, dilihat dari pendidikan terakhir responden

2. Elemen-elemen Modal Sosial

a) Jaringan social

1) Jaringan dengan orang diluar desa

2) Hubungan dengan sesama petani Captikus

3) Hubungan antara penampung dan petani captikus

4) Kerjasama antara Penampung dan Petani Captikus

b) Kepercayaan

1) Saling percaya terhadap sesama petani Captikus

2) Saling percaya antara Petani dengan Penampung Captikus

3) Saling membantu antara Penampung dan Petani Captikus

c) Norma sosial

1) Petani dalam kehidupan bermasyarakat di desanya bisa mematuhi tata tertib atau Norma sosial yang berlaku

2) Adanya aturan-aturan yang mengatur sistem kerja diantara sesama Petani Captikus

3) Adanya aturan-aturan yang mengatur sistem kerja dan sistem bayar kinerja antara Petani dan Penampung Captikus.

\section{Metode Analisis Data}

Analisis Data yang digunakan adalah skalalikert secara kualitatif dan di deskripsikan untuk mengukur menggunakan skala likert 
untuk mengetahui modal sosial dalam usaha captikus di Desa Ranolambot Kecamatan Kawangkoan Barat. Menurut Soegiyono dalam Sunyoto (2014) skala likert adalah skala yang digunakan untuk mengukur sikap, pendapat dan persepsi seseorang atau kelompok orang menjelaskan tentang fenomena seseorang.

Dalam penelitian ini disusun 3 pernyataan dan jawaban setiap instrument berupa kata-kata yaitu:

$$
\begin{aligned}
& \mathrm{B}=\text { Baik } \\
& \mathrm{CB}=\text { Cukup Baik } \\
& \text { TB }=\text { Tidak Baik } \\
& \text { Bila: } \\
& \text { B diberi skor }=3 \\
& \text { CB diberi skor }=2 \\
& \text { TB diberi skor }=1
\end{aligned}
$$

Dengan cara perhitungan skor masingmasing pernyataan:

Maka jumlah skor tiap kriteria = capaian skor $\mathrm{X}$ jumlah responden

$$
\begin{aligned}
& \mathrm{S} 3=3 \times 30=90 \\
& \mathrm{~S} 2=2 \times 30=60 \\
& \mathrm{~S} 1=1 \times 30=30
\end{aligned}
$$

Jumlah skor ideal untuk setiap pernyataan skor $($ tertinggi $)=90 \mathrm{dan}$ jumlah skor $($ terendah $)$ $=30$.

\section{HASIL DAN PEMBAHASAN}

\section{Deskripsi Wilayah Penelitian}

\section{Letak Wilayah}

Desa Ranolambot merupakan salah satu desa yang ada di Kecamatan Kawangkoan Barat, Kabupaten Minahasa, Provinsi Sulawesi Utara. Terdiri dari 5 Jaga/Dusun dengan batas wilayah sebagai berikut:

- Sebelah Utara berbatasan dengan Desa Rumoong Kecamatan Tareran

- Sebelah Timur berbatasan dengan Desa Tombasian Bawah

- Sebelah Selatan berbatasan dengan Desa Kotamenara

- Sebelah Barat berbatasan dengan Desa Tumaluntung

\section{Jumlah Penduduk}

Jumlah Penduduk : 1210 Jiwa

- Laki-laki : 615 Jiwa

- Perempuan : 595 Jiwa

Jumlah Kepala Keluarga: 361 KK

\section{Karakteristik Responden}

\section{Umur Responden}

Menurut Mardikanto (2009), petani yang masih tergolong muda justru lebih cekatan, produktif serta lebih mudah menerima adopsi inovasi dibandingkan dengan petani yang tergolong tua. Komposisi umur responden dalam penelitian ini dapat dilihat pada Tabel 1 .

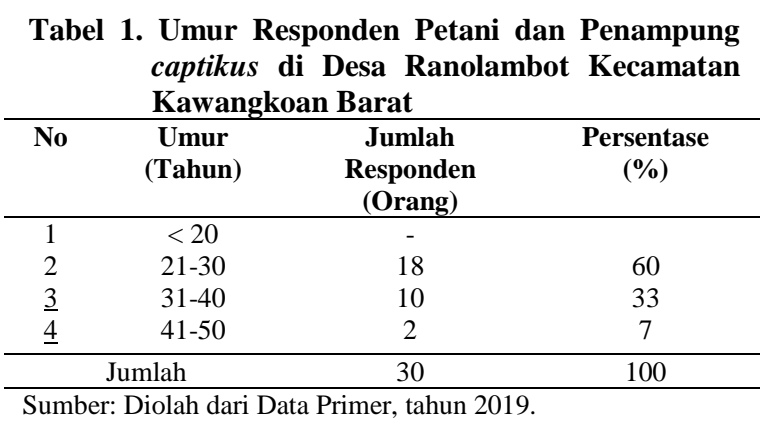

Tabel 1 menunjukkan bahwa jumlah responden terbanyak berada padainterval umur 21-30 tahun, dan selanjutnya pada interval umur 31-40 tahun dan paling sedikit responden yang berada pada interval 41-50 tahun.

\section{Tingkat Pendidikan Responden}

Tabel 2 menunjukkan tingkat pendidikan yang dimiliki penampung dan petani captikus. Tingkat pendidikan responden paling banyak yaitu SD sebanyak 23 orang $(76,66 \%)$, sedangkan tingkat SMP 4 orang $(13,33 \%)$, tingkat SMA/SMK sebanyak 3 orang $(10,00 \%)$, dan pada tingkat perguruan tinggi tidak ada.

Tabel 2. Responden Modal sosial dalam usaha captikus di Desa Ranolambot Kecamatan Kawangkoan Barat berdasarkan Tingkat Pendidikan

\begin{tabular}{llcc}
\hline No & $\begin{array}{l}\text { Tingkat } \\
\text { Pendidikan }\end{array}$ & $\begin{array}{c}\text { Jumlah } \\
\text { responden } \\
\text { (orang) }\end{array}$ & $\begin{array}{c}\text { Persentase } \\
(\boldsymbol{\%})\end{array}$ \\
\hline 1 & SD & 23 & 76,66 \\
2 & SMP & 4 & 13,33 \\
3 & SMA/SMK & 3 & 10,00 \\
\hline \multicolumn{4}{l}{ Sumber: Diolah dari Data Primer, tahun 2019. }
\end{tabular}




\section{Modal Sosial Petani dan Penampung Captikus di Desa Ranolambot Kecamatan Kawangkoan Barat.}

Modal sosial menjadi syarat yang harus dipenuhi bagi pembangunan manusia, pembangunan ekonomi, sosial ekonomi, sosial dan politik. Menurut Inayah (2012), Modal sosial yang lemah akan meredupkan semangat gotong royong, memperparah kemiskinan, meningkatkan pengangguran, kriminalitas, dan menghalangi setiap usaha untuk meningkatkan kesejahtraan penduduk. Modal sosial merupakan sumberdaya sosial yang dapat dipandang sebagai investasi untuk mendapatkan sumberdaya baru dalam masyarakat. Oleh karena itu modal sosial diyakini sebagai salah satu komponen utama dalam menggerakan kebersamaan, mobilitas ide, saling kepercayaan dan saling menguntungkan sebagai kemajuan bersama.

Petani dan penampung Captikus terdiri dari individu-individu yang tergabung dalam sebuah hubungan sosial dengan melakukan interaksi yang ditopang oleh kepercayaan, norma dan jaringan yang memungkinkan efisiensi dan efektifitas dalam penelitian ini dilihat dari unsur pokok modal sosial yang terdapat dalam modal sosial, sehingga didapatkan pembagian unsur pokok yang didasarkan pada berbagai pengertian modal sosial yang telah ada, yaitu: jaringan sosial, kepercayaan dan norma-norma sosial.

\section{Jaringan Sosial}

Tabel 3 menunjukkan modal sosial petani captikus dan penampung yang menjelaskan tentang jaringan sosial yang terbentuk diantara mereka sesama petani captikus, penampung orang di luar desa dalam kerjasama diantara mereka.

Tabel 3. Rekapitulasi Jaringan sosial dalam Modal sosial sebagai Petani dan penampung captikus di Desa Ranolambot

\begin{tabular}{clcc}
\hline No & \multicolumn{1}{c}{ Indikator } & $\begin{array}{c}\text { Jumlah } \\
\text { responden }\end{array}$ & Skor \\
\hline 1 & $\begin{array}{l}\text { Jaringan dengan orang } \\
\text { diluar desa }\end{array}$ & 30 & 60 \\
2 & $\begin{array}{l}\text { Hubungan antara sesama } \\
\text { petani captikus }\end{array}$ & 30 & 90 \\
3 & $\begin{array}{l}\text { Hubungan antara petani } \\
\text { dan penampung captikus }\end{array}$ & 30 & 90 \\
4 & $\begin{array}{l}\text { Kerjasama antara petani } \\
\text { dan penampung captikus }\end{array}$ & 30 & 90 \\
\hline \multicolumn{2}{c}{ Total } & 120 & 330 \\
\hline
\end{tabular}

Sumber : Diolah dari Data Primer, tahun 2019.

\section{Jaringan dengan orang diluar desa}

Hasil penelitian diatas dalam jaringan dengan orang diluar desa berada pada skor 60 dan menunjukkan bahwa $100 \%$ (30 orang) memiliki hubungan yang Cukup baik dengan orang di luar desa disebabkan rata-rata penampung maupun petani di Desa Ranolambot masih kurang dalam jaringan dengan orang luar desa karena masih memakai perantara ketika akan menjual produk captikus diluar desa atau di perusahan yang akan membeli captikus tersebut.

\section{Hubungan antara sesama petani captikus}

Dari indikator jaringan ini ingin dilihat apakah responden yang dalam penelitian ini adalah petani dan penampung captikus yang memiliki hubungan yang baik antara sesama penampung dan petani captikus.

Hasil penelitian diatas dalam hubungan antara sesama petani captikus berada pada skor 90 dan ini menunjukkan bahwa $100 \%$ (30 orang) setuju bahwa hubungan mereka antar sesama petani captikus baik karena sesama petani saling membutuhkan. Contohnya ketika ada petani yang tidak memiliki Pohon enau ataupun Pohon enau petani yang lain itu sudah tidak bisa digunakan lagi untuk sementara waktu maka petani yang lain meminjamkan pohon enau mereka untuk digunakan tetapi saat penjualan captikus maka penjualannya dibagi rata.

\section{Hubungan antara Penampung dan Petani Captikus}

Dalam suatu komunitas atau lingkungan bermasyarakat perlu tercipta hubungan yang baik antara sesama penampung dan petani captikus, perlu ada jaringan yang menunjang keberlangsungan hidup setiap masyarakat. Penampung dan petani captikus ketika ingin menunjang keberlangsungan hidup dan keluarganya perlu menciptakan jaringan dengan anggota masyarakat desanya. Tanpa membangun hubungan yang baik antar sesama penampung dan petani captikus maka penampung dan petani captikus akan sulit untuk berkomunikasi bahkan untuk membangun jaringan akan sulit. Jaringan merupakan komponen modal sosial yang menentukan apakah penampung dan petani captikus bisa bertahan hidup dengan cara menjalin relasi yang baik. 
Hasil penelitian diatas dalam hubungan antara penampung dan petani captikus berada pada skor 90 dan ini menunjukkan bahwa $100 \%$ (30 orang) setuju bahwa hubungan mereka antar sesama penampung dan petani captikus baik, karena mereka saling membantu, saling memahami kalau ada petani yang mengalami kesulitan ekonomi. Contohnya dalam Hal penampung meminjamkan uang/modal terlebih dahulu kepada petani tanpa Captikus yang mereka masukkan terlebih dahulu.

\section{Kerjasama antara Penampung dan Petani captikus}

Hasil penelitian diatas dalam hal kerjasama antara penampung dan petani captikus berada pada skor 90 dan ini menunjukkan bahwa $100 \%$ (30 orang) memiliki hubungan kerjasama yang baik karena ketika ada petani yang bersedia meminjamkan pohon seho kepada petani yang lain jadi ada kerjasama yang harus dibuat yaitu dengan membagi biaya penjualan dari captikus tersebut.

\section{Kepercayaan}

Tabel 4 memperlihatkan modal sosial dalam kepercayaan yang ditunjukkan antara penampung dan petani captikus.

\begin{tabular}{|c|c|c|c|}
\hline Tabel & $\begin{array}{l}\text { 4. Rekapitulasi } \\
\text { Modal sosial } \\
\text { penampung } \\
\text { Ranolambot }\end{array}$ & $\begin{array}{l}\text { Kepercayaan se } \\
\text { antara Petani } \\
\text { Captikus di }\end{array}$ & $\begin{array}{r}\text { bagai } \\
\text { dan } \\
\text { Desa }\end{array}$ \\
\hline No & Indikator & $\begin{array}{c}\text { Jumlah } \\
\text { Responden }\end{array}$ & Skor \\
\hline 1 & $\begin{array}{l}\text { Saling percaya } \\
\text { terhadap sesama } \\
\text { Petani captikus }\end{array}$ & 30 & 90 \\
\hline 2 & $\begin{array}{l}\text { Saling percaya } \\
\text { antara } \\
\text { Penampung } \\
\text { dengan Petani } \\
\text { Captikus }\end{array}$ & 30 & 30 \\
\hline 3 & $\begin{array}{l}\text { Saling } \\
\text { membantu antara } \\
\text { Penampung dan } \\
\text { Petani Captikus }\end{array}$ & 30 & 90 \\
\hline Total & & & 210 \\
\hline
\end{tabular}

Tabel 4 menunjukkan kepercayaan terhadap penampung dan petani captikus berdasarkan hasil wawancara dengan petani dan penampung responden.

\section{Kepercayaan \\ Saling percaya terhadap sesama Petani captikus}

Kepercayaan merupakan salah satu komponen modal sosial yang sangat menentukan apakah dalam satu komunitas bisa terjalin hubungan yang baik ataun tidak. Pernyataan ini ingin melihat apakah responden yang dalam penelitian ini memiliki hubungan saling percaya antar sesame petani captikus.

Hasil penelitian diatas dalam hal saling percaya terhadap sesama petani captikus berada pada skor 90 dan ini menunjukkan bahwa 100\% (30 orang) setuju bahwa mereka bisa saling percaya terhadap sesama petani captikus dikarenakan karena sesama petani captikus saling percaya contohnya, soal petani yang meminjamkan modal usaha ataupun tempat pengolahan captikus.

\section{Saling percaya antara Petani dan penampung Captikus}

Hasil penelitian diatas dalam hal saling percaya antara penampung dan petani captikus berada pada skor 30 dan ini menunjukkan bahwa 100\% (30 orang) Tidak baik dalam sikap saling percaya antara penampung dan petani captikus karena ada petani yang telah terlebih dahulu meminjam modal atau uang kepada penampung captikus tanpa terlebih dahulu membawa captikus kepada penampung karena masalahnya ada petani yang butuh uang terlebih dahulu tapi setelah itu tidak dikembalikan modal atau uang dari penampung tersebut.

\section{Saling membantu antara Penampung dan Petani Captikus}

Hasil penelitian diatas dalam hal saling membantu antara petani dan penampung captikus berada pada skor 90 dan ini menunjukkan bahwa 100\% (30 orang) setuju bahwa diantara sesama petani dan penampung captikus, saling membantu apalagi soal kebutuhan hidup keluarga mereka.

\section{Norma sosial}

Berikut ini memperlihatkan modal sosial dalam norma sosial yang ditunjukkan antara petani dan penampung captikus. 
Tabel 5. Rekapitulasi Norma sebagai Modal sosial antara Petani dan penampung captikus di Desa Ranolambot

\begin{tabular}{llcc}
\hline No & Indikator & $\begin{array}{c}\text { Jumlah } \\
\text { Responden }\end{array}$ & Skor \\
\hline 1 & $\begin{array}{l}\text { Petani dan Penampung } \\
\text { dalam } \\
\text { bermasyarakat di Desanya } \\
\text { bisa mematuhi tata tertib }\end{array}$ & 30 & 90 \\
& atau Norma sosial yang & & \\
& berlaku. & & \\
2 & $\begin{array}{l}\text { Adanya aturan-aturan yang } \\
\text { mengatur sistem kerja }\end{array}$ & 30 & 90 \\
& $\begin{array}{l}\text { diantara sesama Petani } \\
\text { Captikus }\end{array}$ & & \\
& $\begin{array}{l}\text { Adanya aturan-aturan yang } \\
\text { mengatur sistem kerja dan } \\
\text { sistem bayar kinerja antara }\end{array}$ & 30 & 90 \\
& $\begin{array}{l}\text { Petani dan Penampung } \\
\text { Captikus }\end{array}$ & \\
\hline Total & & & \\
\hline
\end{tabular}

Hasil penelitian diatas dalam hal adanya aturan-aturan yang mengatur sistem kerja diantara sesama petani captikus berada pada skor 90 dan ini menunjukkan bahwa $100 \%$ (30 orang) setuju dengan adanya aturan-aturan yang mengatur sistem kerja diantara sesama petani captikus. Contohnya dalam hal peminjaman modal atau uang ataupun pohon seho yang di pinjamkan kepada petani yang lain mereka patuhi.

\section{Adanya aturan-aturan yang mengatur sistem kerja dan sistem bayar kinerja antara Petani dan penampung Captikus}

Hasil penelitian diatas dalam hal adanya aturan-aturan yang mengatur sistem kerja dan sistem bayar kinerja antara penampung dan petani captikus berada pada skor 90 dan ini menunjukkan bahwa $100 \%$ (30 orang) setuju dengan adanya aturanaturan yang mengatur sistem kerja dan sistem bayar kinerja antara petani dan penampung captikus. Karena setiap penampung captikus telah membuat kesepakatan dan telah mengatur sistem bayar kinerja sesuai kadar captikus yang mereka jual kepada penampung captikus.

\section{KESIMPULAN DAN SARAN}

\section{Kesimpulan}

Berdasarkan hasil penelitian modal sosial dalam usaha captikus di Desa Ranolambot Kecamatan Kawangkoan Barat berdasarkan ketiga komponen modal sosial yaitu :

1) Jaringan sosial berada pada kategori Cukup Baik karena jaringan dengan orang diluar desa masih kurang karena ketika penampung dan petani captikus di Desa Ranolambot melakukan penjualan captikus diluar desa maupun di perusahan-perusahan luar harus memakai perantara agar supaya captikus akan terjual.

2) Kepercayaan berada pada kategori Cukup Baik karena Kepercayaan antara penampung dan petani captikus harus lebih ditingkatkan lagi oleh rasa saling percaya karena ketika ada petani yang terlebih dahulu mengambil uang kepada penampung captikus seharusnya uang itu akan diganti dengan captikus tetapi ada petani lain yang tidak mengembalikan uang itu karena sudah berpindah ke penampung captikus yang lain.

3) Norma sosial berada pada kategori Baik dikarena penampung dan petani captikus mematuhi segala aturan-aturan yang berlaku baik sesama petani maupun penampung dengan pemerintah di Desa tersebut contohnya dalam hal surat ijin penampung captikus, sebelum penampung captikus melakukan usaha untuk menjadi penampung mereka sudah telebih dahulu membuat surat ijin penampung captikus.

\section{Saran}

Bagi para penampung dan petani captikus agar dapat mempertahankan modal sosial yang sudah terjalin dengan baik, sesuai dengan norma-norma yang ada di desa tersebut. Tingkat kepercayaan dan jaringan yang berkaitan dengan tingkat pendidikan harus lebih ditingkatkan agar supaya lebih banyak jaringan dengan orang di luar desa dan bisa mempermudah para penampung captikus di Desa Ranolambot dalam menjual produk captikus di luar desa maupun di perusahan-perusahan yang membutuhkan captikus. 


\section{DAFTAR PUSTAKA}

Ahmad Erani Yustika, 2006, Ekonomi Kelembagaan: Definisi, Teori, dan Strategi, Bayumedia, Malang.

Coleman, James S. 1990. Foundation of Social Theory. Cambrige, MA: Harvard University Press.

Danang Sunyoto. 2012. Dasar-dasar Manajemen Pemasaran. Cetakan Pertama. Yogyakarta: CAPS.
Inayah 2012. Peran Modal Sosial Dalam Pembangunan: Jurnal Pengembangan Humaniora, Vol.12, hal.43-47.

Putnam R,1993, The Prosperous Community; SOSIAL Capital and Public Life.

Mardikanto, 2009. Sistem Penyuluhan Pertanian. Sebelas Maret University Press. Surakarta. 